\title{
Accuracy of Models Obtained from Digital Impressions Versus Scanning of Conventional Impressions
}

\section{Research Article}

Keywords:

Posted Date: September 20th, 2021

DOI: https://doi.org/10.21203/rs.3.rs-802865/v2

License: (c) (i) This work is licensed under a Creative Commons Attribution 4.0 International License.

Read Full License 


\section{Abstract}

The full text of this preprint has been withdrawn, as it was submitted in error. Therefore, the authors do not wish this work to be cited as a reference. Questions should be directed to the corresponding author.

\section{Full Text}

The authors have withdrawn this preprint from Research Square. 